\title{
A pulsating $\mathrm{H} 2 \mathrm{O}$ approach to improve biochar reactivity and syngas quality: Mechanism, priority and optimum
}

\author{
Guozhang Chang ${ }^{1}$, Xintong $\mathrm{Guo}^{2}$, Jingjing $\mathrm{Ma}^{2}$, Lingyun Wang ${ }^{3}$, and Qingjie Guo ${ }^{3}$ \\ ${ }^{1}$ Shandong University of Science and Technology \\ ${ }^{2}$ Ningxia University \\ ${ }^{3}$ Qingdao University of Science and Technology
}

July 14, 2020

\begin{abstract}
The reaction of biochar-CO2 $(\mathrm{C}-\mathrm{CO} 2)$ is the speed-control reaction in a real-world gasifier. In this study, a new impulsive $\mathrm{H} 2 \mathrm{O}(\mathrm{g})$ approach was introduced and optimized to improve the reactivity and syngas quality from biochar gasification using a TG analyzer and a tube furnace. An interaction of "independent to competitive" effect was observed during D-biochar gasified in $\mathrm{CO} 2 / \mathrm{H} 2 \mathrm{O}(\mathrm{g})$ under diffusion reaction regime. Micropores suitable for C-CO2 was produced by $\mathrm{H} 2 \mathrm{O}(\mathrm{g})$ within a specific stage, which created the desired synergistic effect between $\mathrm{C}-\mathrm{CO} 2$ and $\mathrm{C}-\mathrm{H} 2 \mathrm{O}(\mathrm{g})$. The introduction of pulsating $\mathrm{H} 2 \mathrm{O}(\mathrm{g})$ was employed to supply micropores for $\mathrm{C}-\mathrm{CO} 2$ and avoid the pore expansion effect of $\mathrm{C}-\mathrm{H} 2 \mathrm{O}(\mathrm{g})$ (which is negative to $\mathrm{C}-\mathrm{CO} 2$ ). As a consequence, an improvement on the obtained syngas yield and a remarkable $\mathrm{H} 2 \mathrm{O}(\mathrm{g})$-saving effect were achieved using the new approach on the premise of not significantly reducing the corresponding carbon conversion than using the traditional mixed $\mathrm{CO} 2 / \mathrm{H} 2 \mathrm{O}(\mathrm{g})$ method.
\end{abstract}

\section{Hosted file}

Manuscript.doc available at https://authorea.com/users/342832/articles/469645-a-pulsatingh2o-approach-to-improve-biochar-reactivity-and-syngas-quality-mechanism-priority-andoptimum 